\title{
Fly Ash from the Thermal Transformation of Sewage Sludge as an Additive to Concrete Resistant to Environmental Influences in Communication Tunnels
}

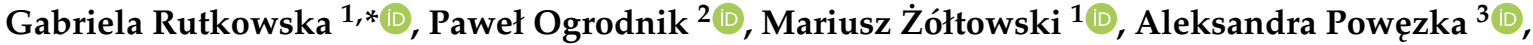 \\ Michał Kucharski ${ }^{1}$ and Martin Krejsa ${ }^{4}$
}

1 Institute of Civil Engineering, Warsaw University of Life Sciences (SGGW), Nowoursynowska 166, 02-787 Warsaw, Poland; mariusz_zoltowski@sggw.edu.pl (M.Ż.); michal_kucharski@sggw.edu.pl (M.K.)

2 Institute of Safety Engineering, The Main School of Fire Service, 52/54 Słowackiego Street, 01-629 Warsaw, Poland; pogrodnik@sgsp.edu.pl

3 Faculty of Safety Engineering and Civil Protection, The Main School of Fire Service, 52/54 Słowackiego Street, 01-629 Warsaw, Poland; apowezka@sgsp.edu.pl

4 Department of Structural Mechanics, VSB-Technical University of Ostrava, 70800 Ostrava, Czech Republic matrin.krejsa@vsb.cz

* Correspondence: gabriela_rutkowska@sggw.edu.pl

Citation: Rutkowska, G.; Ogrodnik,

P.; Żółtowski, M.; Powęzka, A.;

Kucharski, M.; Krejsa, M. Fly Ash

from the Thermal Transformation of

Sewage Sludge as an Additive to

Concrete Resistant to Environmental

Influences in Communication

Tunnels. Appl. Sci. 2022, 12, 1802.

https://doi.org/10.3390/

app12041802

Academic Editors: Diego Gino and

Gabriele Bertagnoli

Received: 20 December 2021

Accepted: 31 January 2022

Published: 9 February 2022

Publisher's Note: MDPI stays neutral with regard to jurisdictional claims in published maps and institutional affiliations.

Copyright: (C) 2022 by the authors. Licensee MDPI, Basel, Switzerland. This article is an open access article distributed under the terms and conditions of the Creative Commons Attribution (CC BY) license (https:// creativecommons.org/licenses/by/ $4.0 /)$.

\begin{abstract}
Concrete is an ecological material with a high potential to adapt to specific operating conditions, and the lowest carbon footprint as it is made from local raw materials-aggregate, cement, water, admixtures, and mineral additives. It is the most widely used composite material among those that are man-made and second only to water in the entire range of materials used. The aim of this research was to assess the possibility of using fly ash from the thermal treatment of sewage sludge as an alternative additive to concretes resistant to environmental influences occurring in communication tunnels. A concrete mix based on CEM I 42.5R Portland cement with various ash content of $0-20 \%$ of the cement mass was designed for the experimental work. In the course of the experimental work, the compressive strength was measured after three maturing periods, and the influence of both high temperature and the material modification on the course of carbonation were determined. The test results confirm the possibility of producing plain concrete, modified with fly ash obtained from the thermal treatment of sewage sludge. The highest average compressive strength of $43.6 \mathrm{MPa}, 45.6 \mathrm{MPa}$, and 51.2 $\mathrm{MPa}$ after 28, 56 and 720 days of maturation, respectively, was for concrete containing $10 \%$ ash.
\end{abstract}

Keywords: concrete; waste-fly ash from sewage sludge; fire protection; tunnels

\section{Introduction}

Tunnel fires can have a catastrophic impact on the community, tunnel systems and others in the vicinity of the structure. The majority of the tunnel fires reported in the last decade were caused by chemical spills. As expected, many of these incidents involved heavy-duty vehicles (HGVs) unclassified as dangerous [1], which suggests that a ban on entering a tunnel by a railway driver would not cause any damage. Fires in underground tunnels can cause a constant increase in temperature, which can last for a long time, since they usually cause inefficient ventilation. Due to the reported fires, the tunnel temperature was significantly higher than $1000^{\circ} \mathrm{C}$ and continued for a few days [2]. As a result, the materials used in the construction of a concrete tunnel are now expected to fulfill a set of restrictive requirements. From time to time, there has been a lot of ash used in their production. The development of the sewerage network and the cleaning of municipal sewerage plants has led to the construction of larger sewers (SS). Approximately 13Mt of dry material is produced annually in the countries of the European Union [3]. The foundry settlements are characterized by a high-water content of up to $95-99 \%$, and as they 
have a non-homogeneous physico-chemical composition, they include azote and potato storage vessels, as well as heavy metals, such as: $\mathrm{Hg}, \mathrm{Zn}, \mathrm{Cd}, \mathrm{Cr}, \mathrm{Cu}, \mathrm{Ni}, \mathrm{Pb}, \mathrm{As}, \mathrm{Sb}, \mathrm{Se}, \mathrm{Ba}$, Mo $[4,5]$. In Europe, the most popular method of utilizing rising settlements is the thermal method. Here, fluid, heating, or revolving boilers [6-8] will reduce the amount of waste (settlement), providing energy is not a sufficient solution, as it generates ash and air, which should be used. Given the importance of a zero-emission economy, ascites from the thermal development of tackle settlements should be treated as a potential material for use in the production of construction materials. The advantage of using airborne ash in building materials is the destruction of pathogens during the traction process, the immobilization of heavy metals in the fired matrix, the suppression of organic matter, and the increase in resistance.

The aim of the research performed on cement composites modified with fly ash from the thermal processing of sewage sludge (SSA) was to assess the possibility of the rational use of such waste as a cement substitute in the production of concrete resistant to high temperatures and the phenomenon of thermal chipping. As part of the pilot tests, in addition to the compressive strength and the depth of water penetration under pressure, the influence of high temperatures on the properties of the designed cement composite was determined. This article also presents the influence of this type of material modification on the course of concrete carbonation as well as the results of the tests and analyzes of the properties of fly ash from sewage sludge. Research on carbonization is currently underway and will be presented in the next publication on the use of fly ash from sewage sludge.

\section{Review of the Literature on the Subject}

The subject of the research and publications [9-11] was the possibility of applying ashes to construction cells, considering the fulfillment of both the environmental and technical criteria. Ash from ash settlements can be used as an active addition to cement production [12]. Moreover, the hydraulic and pozzolanic properties and the chemical composition (earth, iron, lime, clay, magnesia, phosphorus, and oxygen) of these fly ashes are used as a substitute for Portland cement parts in concrete [13].

The amount of SSA ash produced is about 100 times smaller compared to the fly ash generated from the combustion of hard coal or lignite. However, their use is not a significant problem because it is widely used as an active additive to cement binders, concretes, or mortars [14,15].

Much of the research in the literature concerns the influx of ash, representing the part of the Portland cement that is in the property of the extravagant cementitious composites, that are used as essential technical determinants.

In the research [16] concerning mortars, the cement was mentioned to contain an amount of ash from sewage sludge of between 15 and $30 \%$ by weight. One report, which covered $15 \%$ of the population, showed a comparable level of contamination to that conventionally reported; thus, this report does not negatively affect the validity of the findings. The gross burning of the ash causes a drop in extravagance on the squeezing and shredding of the material [17]. In other research performed by these authors, the general impact of the burning of the settlement is described, based on the freshness of the research, which is based on changes in the solution. It has been argued that the partial replacement of cement by ash leads to a reduction in the flexibility of the mix. The use of a superplasticizer is practical. An additional analysis of the use of malting agents from concrete fixtures and concretes showed that this method of ash utilization did not endanger the safety of the natural environment. Ashes from large settlements are found in phosphorus $[18,19]$.

The analysis of the ash hydration process from the settlement, described by Lin (2005), showed that by representing an ash of $20 \%$ of the mass storage of minerals used in the cement production, a solution can be obtained that meets the required cement requirements. Research into crushing and microstructure has confirmed the cement ability of eco-cement in the development of structures and structural concrete [20,21]. Research was also performed on the joint settlement within a high-rise settlement, which can replace 
the cement. The old settlements are lined with limestone, then ground and burnt. The analysis was concerned with the optimal proportions of ash and lime in the composition of the mixture, the conditions of combustion (temperature and time), and the conditions of hardening. It has been found that the tests that cover $50 \%$ of the settlement, which were heated at a temperature of $1000{ }^{\circ} \mathrm{C}$, kept in the air conditions, which then demonstrated the highest resistance to squeezing [22].

Chang et al. confirmed that the addition of ash from a high-impact settlement affects the increase in water absorption resistance within construction materials. In addition, this work reduced the amount of processing required and the amount of material recovered. The most common conditions were obtained at $10 \%$ ash population [23]. This is consistent with the information provided by other authors, where the small amount of ash from the quarry settlement in cementitious materials yields between $5 \%$ and $20 \%[11,21,24]$.

In the Baeza-Brotons research (2014), popular ash was introduced to concrete blocks at $5,10,15$, and $20 \%$. Concrete blocks have been shown to have converged mechanical properties into conventional blocks, 28 days after completion. Further, the addition of ash has been used to reduce water absorption. The blocks in which sand replaced $10 \%$ of the ash showed the best parameters, relating to density, absorption, and capillarity. The use of such a prepared raw material is chosen as it is better for filling the scales than in the application of the standard mixture. This can indicate significant environmental damage due to the lasting survival of the population in the month and the lower washings; in particular, of metal [25].

Chen (2013) analyzed the potential for the use of ash as a cement substrate and/or a sand substrate in construction materials, considering both the technical and environmental criteria. The construction and concrete created by replacing parts of the cement and parts of the sand have shown less persuasiveness for detection and sanding in comparison to traditional waste. It has also been confirmed that, when a stock containing an amount of $10 \%$ is similar, it has a similar mechanical and durability capacity to push for a conventional right. Considering the technical specifications and environmental standards, the exploitation of ash from the settlement in the construction materials is possible [26].

It should be borne in mind that the remediation of the storage and disposal of air ash from the thermal recovery of tackle settlements will generally be used as active additions to concrete. The generality of ashes in the amount of $25 \%$ of the weight of the cement is used to counteract the bonding process and the increase in the number of scraps of concrete and concrete in comparison with the use of cement is increased. However, by extending the finishing time, it is possible to obtain the durability required for structural concrete [27]. It is, therefore, argued that the widespread increase in concrete congestion from co-firing can be attributed to the generality of the phosphate ions, which support the process of cement hydration $[28,29]$.

Sewage sludge ash can be used as an active supplement in the mixing of cement [12]. The chemical composition (silica, iron, calcium, aluminum, magnesium, phosphorus) as well as the hydraulic and pozzolanic properties of ashes from sewage sludge used as a replacement for Portland cement in concrete are analogous to traditional mineral additives [13].

Long-term field research [30] has shown that the introduction of ashes from the settlement into the construction of main roads (under the state war) does not lead to threats to the environment (land, water) by the washing out of heavy metals. Shirodkar et al. (2013) investigated the addition of ash to a hot asphalt mixture as a mineral filler and/or as a crustaceous substrate in a small-scale mixture. The results showed that resistance to asbestos baking and asbestos, covering between $0 \%$ and $2 \%$ of the ash, has been comparable to conventional asphalt [31]. The Tenza-Abril research (2014) also analyzed the preservation of bituminous mixtures fed with ash taken from peasant settlements as a mineral filler. The researchers confirmed that the population can be used in bituminous mixtures in the amount of $2-3 \%$ by weight, strengthening the corresponding position of friendliness and the consistency of the companies in the past, as well as in the public domains. The use of 
bituminous mixtures in addition to ash does not reduce the risk of exposure to chemical traffic, but it can affect the asphalt level of asphalts [32]. The use of ash from settlements as a stabilizing additive for land-cement mixtures used in the construction of dumps and surface chemicals was the subject of research performed by Durante Ingunza et al. (2014). Concentration tests were performed on crushing soil-cement mixtures using a cement content of 3, 6 and 9\% and 5, 10, 20 and 30\% ash content, in both normal and modified cleaning conditions. Then, the pressure was increased for squeezing all of the ash trials. The addition of $20 \%$ ash to the mixture increased the results by $26 \%$ compared to the mixture without the ash [33].

In total, the survey of cementitious composites modified with fly ash from thermal resurfacing has been valued by the possibility of the rational use of such wastes as cement substitutes in the production of high-impact heat-resistant concrete. As part of the pilot research, the resistance to squeezing, the depth of penetration of water under the tank, and the influence of high temperature separation on the properties of the designed cementitious composite were all assessed. This article also presents the effect of this type of material modification on the course of the concrete carbonation, and the results of the research and analysis of the characteristics of lotions obtained from check-in settlements.

This article focuses only on the use of this additive in concrete. This use eliminates the possible emission of heavy metals into the environment (which is confirmed by leaching tests) $[5,34,35]$. The presented research results may be particularly helpful in the design of cement composites used in road construction.

\section{Thermal Fire Conditions in Tunnels}

A well-designed fire scenario for communication tunnels will provide input taxes for each type of requirement needed to carry out forecast and fire protection assessments pertaining to construction safety and human protection. The design fire scenario can be obtained by deterministic methods, where the design curve represents the hottest possible fire, or it can be based on the analysis of the risk [36]. The safety of the fire tunnel is a combination of a set of elements needed to execute the accepted scenario of the described temperature-time curve. In general, there are several curves describing a fire that starts in a tunnel. One of the most frequently exploited is the RWS curve, which remained in the early 1980s in the Netherlands [37]. There are two groups of curves used in Germany, but also considered in China, by the RABT, which in the first five minutes of the fire was $1200{ }^{\circ} \mathrm{C}$. The described curves are presented in Figure 1.

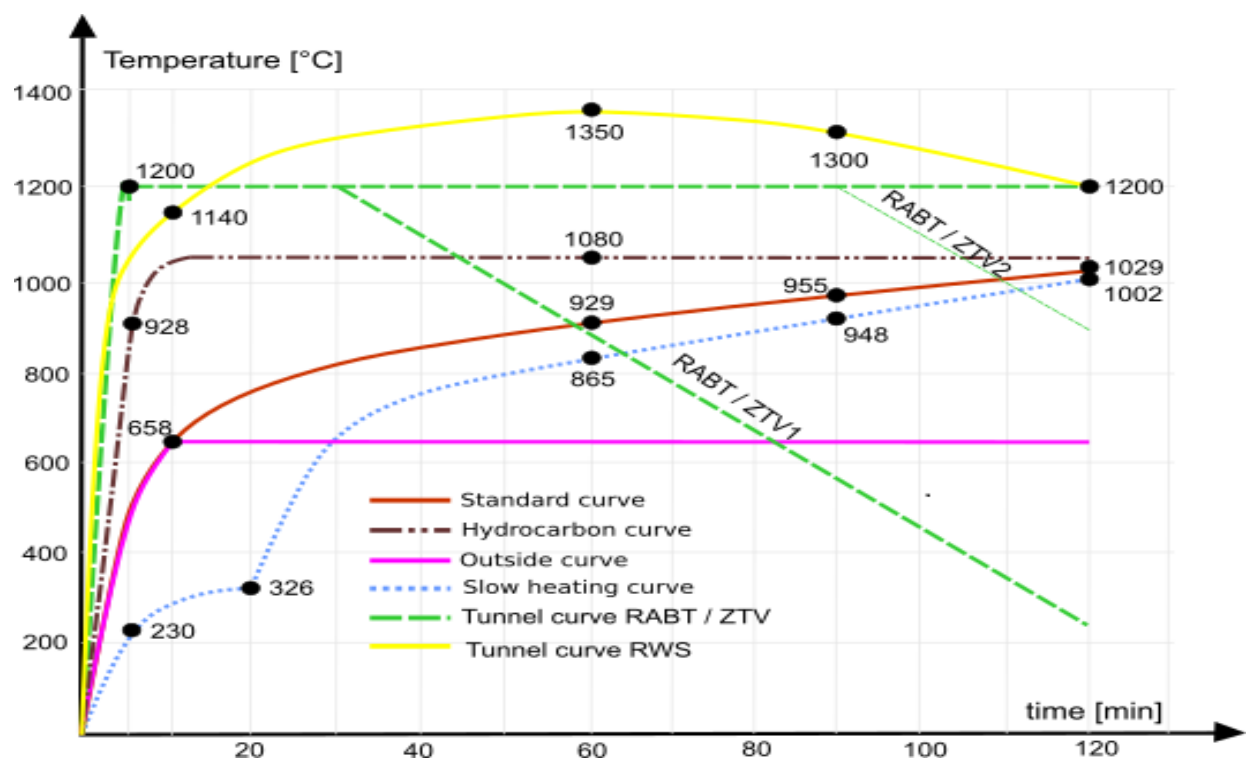

Figure 1. Comparison of fire curves. 
In comparison with the curves used to investigate the resistance of the structural elements, the development of the fire in the tunnel is characterized by greater dynamics and by what can increase the temperature. Apart from the fact that concrete itself is a non-combustible material, it is the constant increase in temperature that causes damage. Explosive combustion is the most dangerous type of concrete blasting. It emits within 20-30 min of a fire starting, when the temperature in the concrete is $150-300{ }^{\circ} \mathrm{C}$ [38-40]. The reason for the explosive burning of concrete is the act of securing the heated concrete of two mechanisms. First, it increases the water vapor pollution in the foundations of the concrete. The second mechanism is the development of the dispersal of discharges caused by the thermal decontamination of concrete. The rise of the temperature gradient results in an increase in the cross-section between the concrete rails, and this can lead to the appearance of spalling [41-44].

\section{Materials and Methods}

As part of the experimental research, a concrete mix of ordinary cobs C20/25 on consistency S2 was designed according to the PN-EN 206+A2:2021-08 method of three equations by Bukowski. The concrete mix was made of CEM I 42.5 R Portland cement (Cement Ożarów SA, Ożarów, Poland), in accordance with the requirements specified in PN-EN 197-1:2012; natural slag with a 0-16 mm according to PN-EN 12620+A1:2010; and water compliant with PN-EN 1008:2004. The components of the mixture are show in Figure 2. In all of the tests, the same scrapper composition was collected at the base of the curved crossings 0-16 mm (Figure 3). As a mineral supplement to the concrete mix, a fly ash from the fluid combustion of municipal settlements in the "Płaszów II" sowing plant in Kraków was used. The physical and chemical parameters, and the phase composition of Portland cement used are shown in Tables 1 and 2. The incineration technology for high-pressure fluids at a temperature of around $900{ }^{\circ} \mathrm{C}$, generally used for candles, is the most effective method of thermal transfer. It guarantees both apartment security and protects the environment. The resulting fly ash is a dry material of a characteristic red-pink color, which varies greatly from ash derived from ash burning, the color of which oscillates in the rock [45-48].
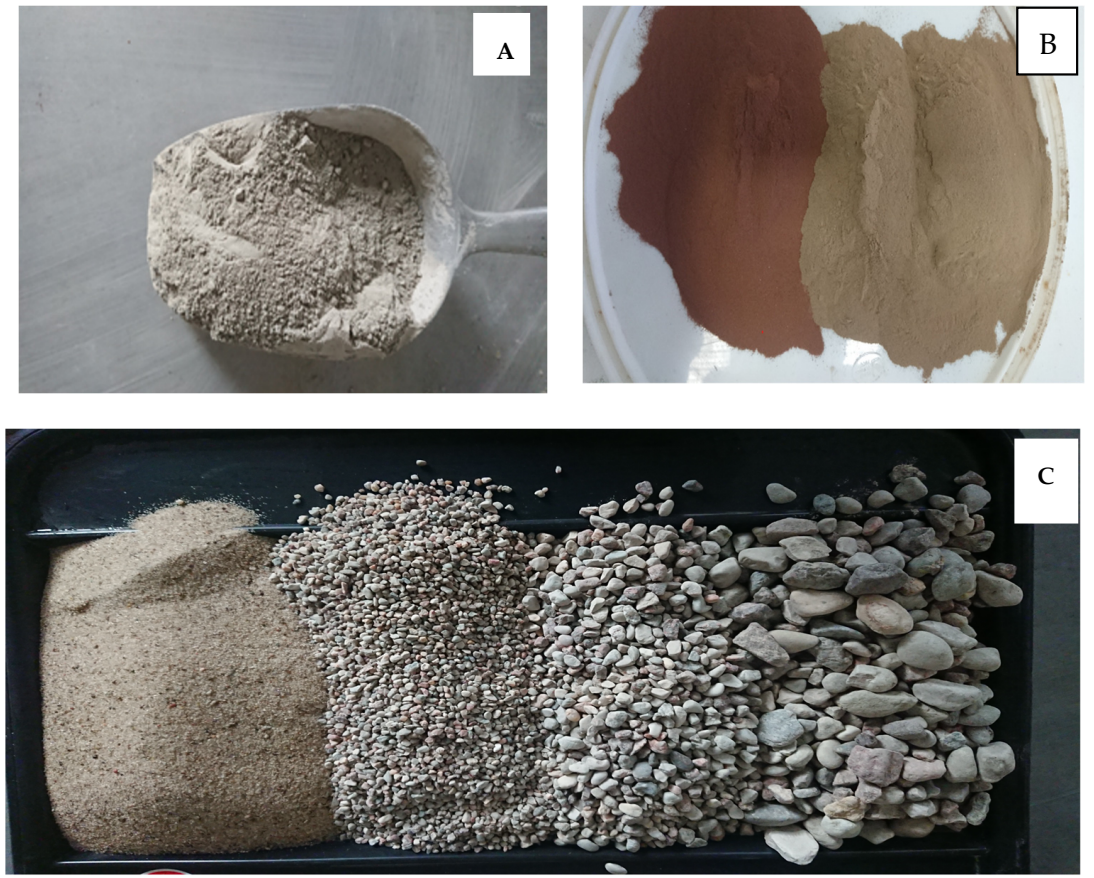

Figure 2. Concrete mixers: cement, settlement ash, leachate: (A) cement; (B) natural slag; (C) aggregate. 


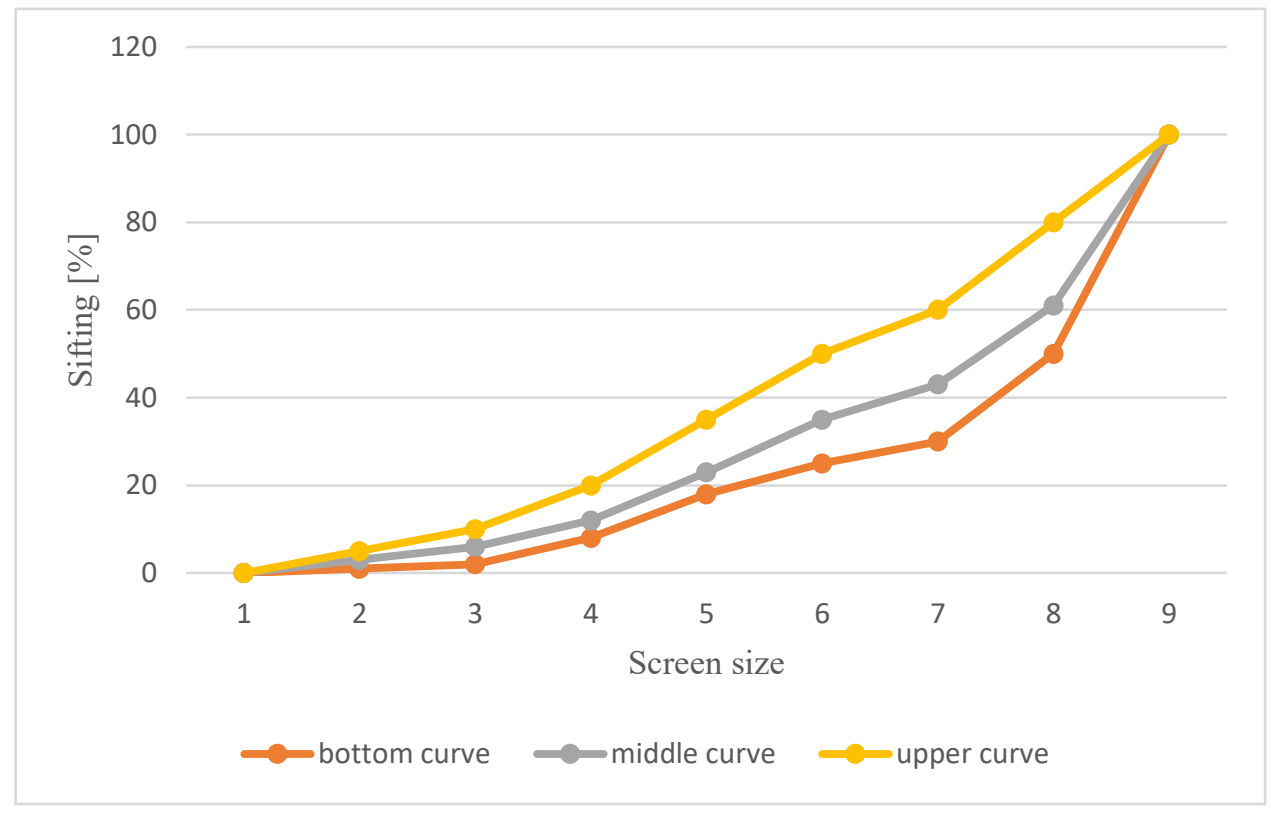

Figure 3. The concrete is crushed into a concrete mixer.

Table 1. Physical properties and phase composition of cement CEM I 42.5 R.

\begin{tabular}{cccc}
\hline $\begin{array}{c}\text { Specific Surface Area } \\
\text { Blaine' } \mathbf{a}\left[\mathbf{c m}^{2} / \mathbf{g}\right]\end{array}$ & $\begin{array}{c}\text { Beginning of Binding Time } \\
\text { [min] }\end{array}$ & $\begin{array}{c}\text { Compressive Strength after } \\
\text { 2 Days [MPa] }\end{array}$ & $\begin{array}{c}\text { Compressive Strength after } \\
\text { 28 Days [MPa] }\end{array}$ \\
\hline 3328 & 219 & 21.0 & 49.7 \\
\hline $\mathrm{C}_{3} \mathrm{~S}-55.53$ & \multicolumn{2}{c}{ The share of mineral phases CEM I [5 mass] } & \\
\hline $\mathrm{C}_{2} \mathrm{~S}-14.58$ & $\mathrm{C}_{3} \mathrm{~A}-8.16$ & $\mathrm{C}_{4} \mathrm{AF}-6.84$ \\
\hline
\end{tabular}

Table 2. Chemical properties of cement CEM I 42.5R.

\begin{tabular}{|c|c|c|c|c|}
\hline Roasting Loss [\%] & Sulfate Content $\mathrm{SO}_{3}[\%]$ & Chloride Content $\mathrm{Cl}[\%]$ & Alkali Content $\mathrm{Na}_{2} \mathrm{O}_{\mathrm{eq}}[\%]$ & $\mathrm{SiO}_{2}[\%]$ \\
\hline 3.18 & 2.97 & 0.05 & 0.76 & 20.20 \\
\hline $\mathrm{Al}_{2} \mathrm{O}_{3}$ & $\mathrm{Fe}_{2} \mathrm{O}_{3}$ & $\mathrm{CaO}$ & $\mathrm{CaO}_{\mathrm{w}}$ & $\mathrm{MgO}$ \\
\hline 4.40 & 2.43 & 64.37 & 1.97 & 1.98 \\
\hline
\end{tabular}

To carry out the analysis of the possibility of exploitation as a partial substitute for cement ash in the areas of thermal rescue of prepared settlements, the mixture was prepared based on the various content of the supplement $(0 \%, 5 \%, 10 \%, 15 \%, 20 \%)$-completing the optimization of water and cement and considering the volume of the interchangeable components-Table 3.

Table 3. Concrete mix proportions by weight.

\begin{tabular}{|c|c|c|c|c|}
\hline \multirow{2}{*}{ Specification } & \multicolumn{4}{|c|}{ Mass of Concrete Ingredients $\left[\mathrm{kg} / \mathrm{m}^{3}\right]$} \\
\hline & Water & Aggregate & Cement & Fly Ash \\
\hline Concrete BZ & 187.11 & 1834.27 & 374.21 & - \\
\hline Concrete with quantity $5 \%$ of fly ash-FA5\% & 187.11 & 1834.27 & 355.50 & 18.71 \\
\hline Concrete with quantity $10 \%$ of fly ash-FA $10 \%$ & 187.11 & 1834.27 & 336.79 & 37.42 \\
\hline Concrete with quantity $15 \%$ of fly ash-FA15\% & 187.11 & 1834.27 & 318.08 & 56.13 \\
\hline Concrete with quantity $20 \%$ of fly ash-FA20\% & 187.11 & 1834.27 & 299.37 & 74.84 \\
\hline
\end{tabular}


As part of the evaluation of the properties of the concrete mix with the addition of fly ash from the thermal treatment of sewage sludge, tests were performed on the prepared slurries: apparent density (PN-EN 12350-6:2011); consistency by the drop cone method (PN-EN 12350-2:2011); and the pressure method air content (PN-EN 12350-7:2011). The methodology of the research on the effect of sewage sludge ash on the compressive strength after 28, 56 and 720 days of maturation was developed based on PN-EN 12390-3:2011. The strength tests were conducted with the use of hydraulic work H011 Matest (Italy). The tests were performed on cubic samples with dimensions of $10 \mathrm{~cm} \times 10 \mathrm{~cm} \times 10 \mathrm{~cm}$, prepared in plastic molds and compacted on a vibrating table. In addition, the samples were tested for their resistance to high temperature; their susceptibility to water penetration under pressure, according to PN-EN 12390-08 on cubic samples with dimensions of $15 \mathrm{~cm} \times 15 \mathrm{~cm} \times 15 \mathrm{~cm}$; and the influence of carbon dioxide-carbonation [46-50]. The carbonation test was performed in a carbonation chamber based on PN-EN 13295:2005 on $10 \mathrm{~cm} \times 10 \mathrm{~cm} \times 50 \mathrm{~cm}$ beams. The samples were demolded after one day, following which, the samples were transferred to the care bath, where they were stored until the individual tests were performed. The depth of the carbonation front was measured 56 days after the samples were inserted into the carbonation chamber at a carbon dioxide concentration of $3 \%$. A phenolphthalein solution ( $1 \mathrm{~g}$ of phenolphthalein per $70 \mathrm{~g}$ of ethyl alcohol, diluted in $30 \mathrm{~g}$ of distilled water) was used to measure the carbonation front [49-54].

To learn about the physico-chemical properties, there is a need to conduct air pollution research from the thermal development of high-quality settlements. The chemical composition was determined using the energy dispersive X-ray fluorescence (XRF) method on an Epsilon 3 spectrometer (Panalytical). This was tested with a Na-Am measuring instrument for devices equipped with an X-ray Rh $9 \mathrm{~W}, 50 \mathrm{kV}, 1 \mathrm{~mA}, 4096$ channel spectrum analyzer, and 6 measuring filters (Cu-500, Cu-300, Ti, Al-50, Al-200; the polarity activity was specified in PN-EN 450-1:2012 and ASTM C379-65T. The morphology and chemical composition of the microcontroller was transmitted using a FEI SEM Quanta 250 FEG scanning microscope, equipped with a chemical dispersion analysis system for X-ray energy exchange dispersal-EDS (Energy Dispersive X-RayXcopy). Irradiation decomposition was performed using a laser diffraction test using a Mastersizer 3000 analyzer (Malvern Instruments, Malvern, UK). The measure is performed in a dispersing target (demineralized water) in the generality of the ultrasonic probe in the cell of the larger aggregates of the tested probes. The analyzed beam had the size of equivalents ranging from $0.1 \mu \mathrm{m}$ to $1000 \mu \mathrm{m}$. The mineral composition was designed using an X-ray phase analysis (XRD). The measures were performed using a Panalytical X'PERT PRO MPD X-ray diffractometer with a PW 3020 goniometer. The X'PERT Highscore software was used for the given diffraction machines. The identification of the mineral phases were based on the PDF-2 release 2010, formalized by JCPDS-ICDD [55,56].

\section{Results and Discussion}

\subsection{Physical and Chemical Properties of the Airport}

The characteristics of the quality and livelihoods available for municipal sewerage, depend on the type and location of the sewerage system, the amount of water used, industrialization, and the standard of living in the area. The composition and number of checks are subject to change within the annual, monthly, and weekly cycles. It should be borne in mind that the types of municipal seedlings are not the same and the type of lotions arising during combustion in fluid furnaces are not the same either. The incidental waste (waste) is 1901 14, which requires separate management. In Figure 4, the results of the analysis of the ground ash collection, taken from a thermal resurrection of the Czech settlements from the Kraków refueling plant in April, are presented. 


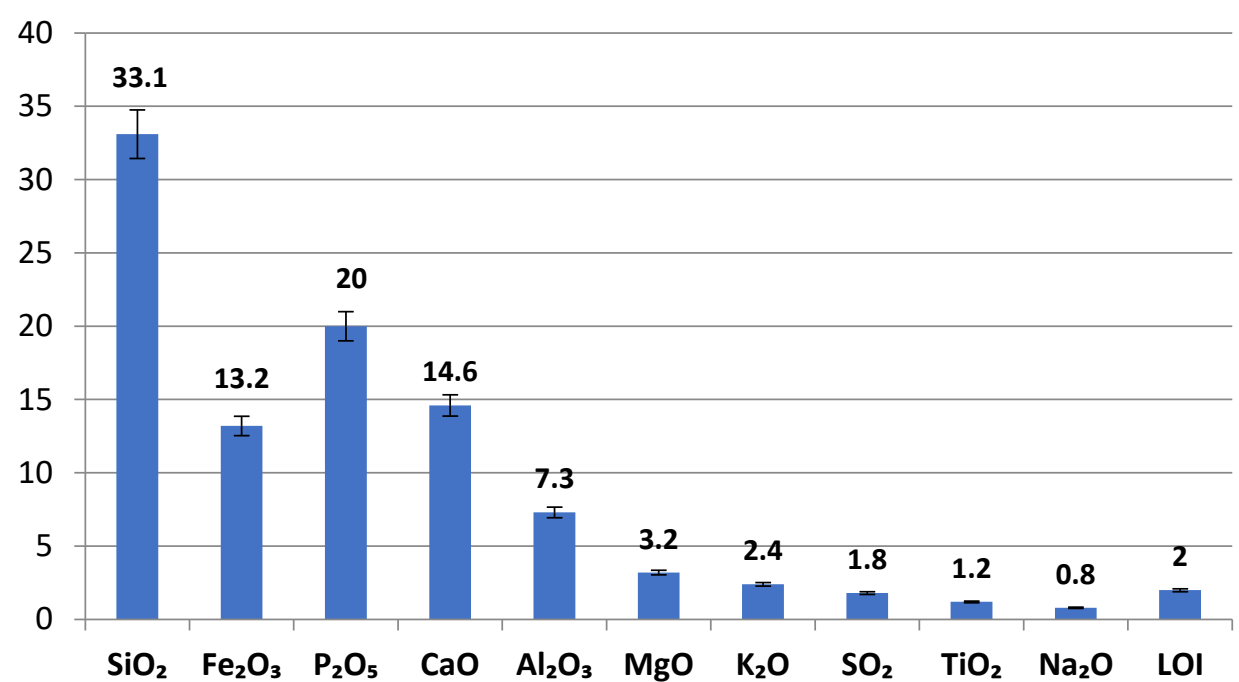

Figure 4. Chemical composition of fly ash from municipal sewage sludge combustion.

Based on the research conducted, it is established that the ash composition from the peasant settlements is similar to that of ash taken from combustion and co-firing of coal containing $\mathrm{SiO}_{2}$. The generality of $\mathrm{SiO}_{2}$ is $33.12 \%$. In addition, the $\mathrm{CaO}$ content of $14.55 \%$, $\mathrm{P}_{2} \mathrm{O}_{5}-20.03 \%$ and $\mathrm{Fe}_{2} \mathrm{O}_{3}-13.25 \%$ was also used in the researched ash. The group of other ash collectors was used for $\mathrm{Al}_{2} \mathrm{O}_{3}$ at $7.25 \%$ and $\mathrm{MgO}$ at $3.23 \%$. In comparison with the combustion ashes, the ashes taken from the thermal relocation of Czech settlements were covered by smaller amounts of $\mathrm{SO}_{3}$. The supplied amount of $\mathrm{P}_{2} \mathrm{O}_{5}$ is suitable for the process of cement hydration. At the beginning of the cement plant, the $\mathrm{PO}_{4}{ }^{3-}$ ions react with $\mathrm{Ca}^{2+}$ ions to form fine-crystalline calcium phosphate on the cement surface. The start of the bond is $30 \mathrm{~h}$, and the end is $40 \mathrm{~h}$. In addition, it is argued that low roasting levels of $0.5 \%$ and phosphorus ions result in resistance to the crushing of concrete produced from their plants [57-60].

Low ash burning loss is related to the temperature (above $850{ }^{\circ} \mathrm{C}$ ) and the technique used for the sewage sludge incineration in a fluidized bed furnace. On the other hand, the much higher content of phosphates in relation to ash seen in coal combustion is due to the removal of the phosphorus from the sewage supplied to the treatment plant and its accumulation in the sludge. The use of this type of ash in concrete requires an extended maturation period. The ability to maintain the properties of the mixture for a long time can be used when it is transported over a long distance [25].

This ash is characterized by a large amount of radiation (conglomerates of radiation) on the average equal value, which is due to their high level of fitness. The degree of equivalence was-702.1\%. The requirement was based on the PN-EN 1097-07:2008 density of the ash content $-2760 \mathrm{~kg} / \mathrm{m}^{3}$; and the bulk density $-815 \mathrm{~kg} / \mathrm{m}^{3}$ frequency based on the PN-EN 451-2:2017-06 published-46.0\% [61,62].

The transmitted chemical analysis in micro-content (SEM-Figure 5) of the popular ash showed dominance: crosslinking, clay, magnesia, iron, and phosphorus. The remaining ingredients are lime and pot. The mineral composition is dominated by quartz, anhydrite and phosphates, which are in the form of apathy and fluorapatite. The distribution of volumes is based on the dominance of the luminous fractions in the range of $20-50 \mu \mathrm{m}-25.25 \%, 50-100 \mu \mathrm{m}-30.39 \%$, and $100-250 \mu \mathrm{m}-23.89 \%$-Figure 6 . 

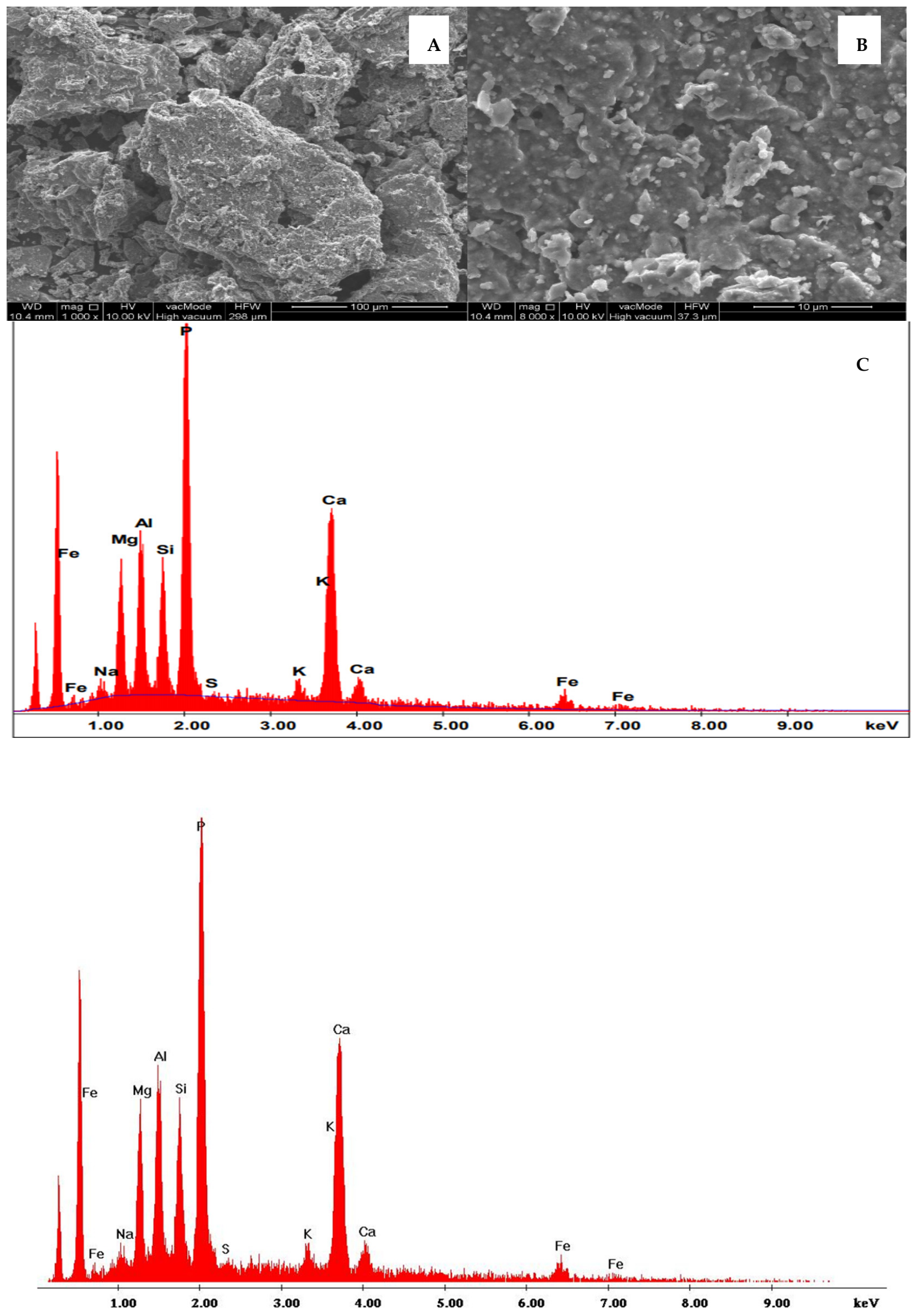

Figure 5. The SEM image of the researched ash from Kraków includes an EVS analysis: (A) ash microstructure; (B) ash microstructure; (C) the oxide composition of the ash. 


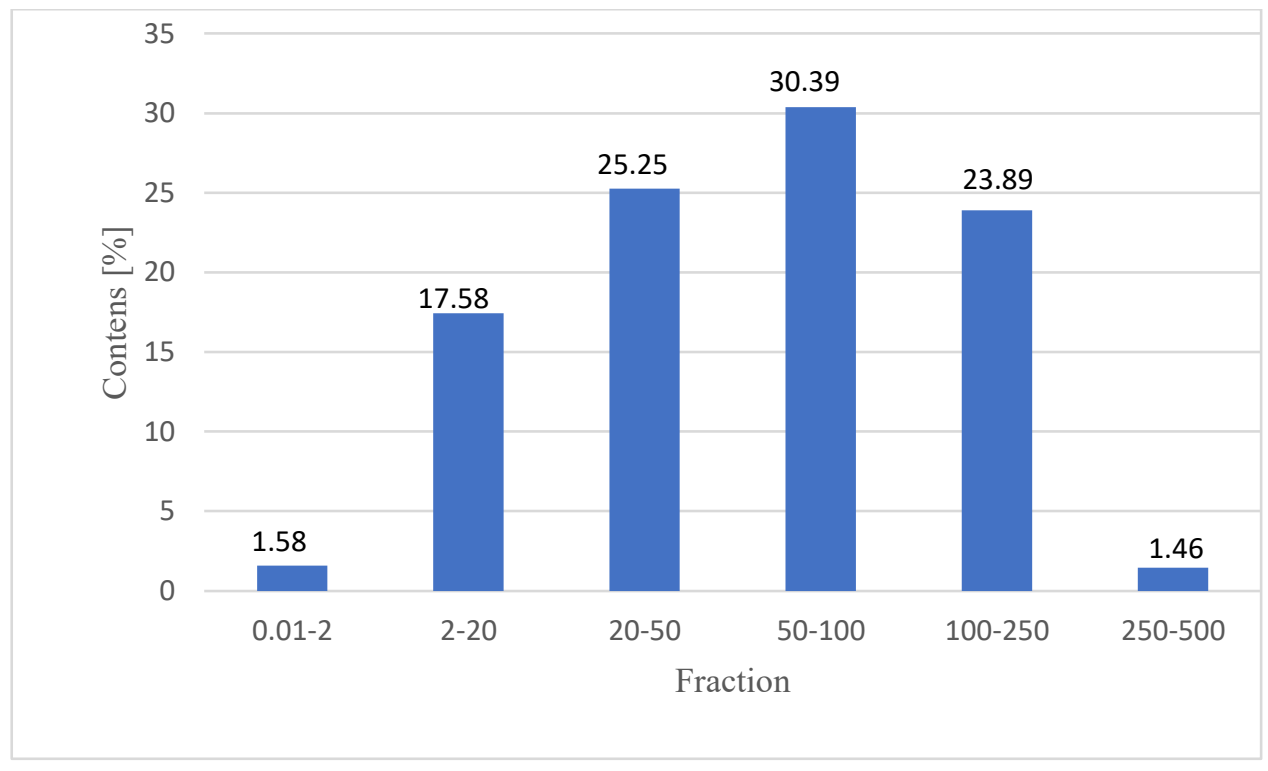

Figure 6. Volume distribution of individual particle fractions in fly ash.

The composition, physical and chemical properties, and technique used to incinerate the ashes from sewage sludge make it similar to those of fly ashes obtained from coal combustion. The presence of the active oxides $\mathrm{CaO}, \mathrm{SiO}_{2}, \mathrm{Al}_{2} \mathrm{O}_{3}$, and $\mathrm{Fe}_{2} \mathrm{O}_{3}$ may have a positive effect on the hardening of mortars and concretes $[63,64]$. The greater presence of alumina- $\mathrm{Al}_{2} \mathrm{O}_{3}$, as well as calcium and sulphate ions compared to Portland cement contributes to the formation of calcium sulphaluminate (AFt) and calcium aluminate (AFm) hydrates $[65,66]$. The presence of SSA in concrete, and the AFm in it can increase its resistance to the harmful effects of chloride [66,67]. An additional benefit of using sludge ash is the ability to immobilize heavy metals $[27,68]$.

\subsection{Property of a Concrete Mixer}

The results of the concrete mix design are presented in Figure 7. As a result of the supplement to the contract-the heat of the air ducts of the settlements is negatively affected by its structure- the concrete quarrel is almost uneven. The concrete mix of the reference concrete (without addition) has a $45 \mathrm{~mm}$ drop; however, the smallest $11 \mathrm{~mm}$ drop is taken up with $20 \%$ of cement ash. This reduction may be attributed to greater compliance with the former addendum. The ash absorbs the free water in the mixture, reducing it in this way. By analogy to the fluidized combustion of coal dust, it can be concluded that the grains of this type of fly ash are characterized by a high content of grains (grain conglomerates) with high open porosity, which translates into high water demand. The degree of porosity for Kraków was $70.86 \%$.

The additive used is characterized by high water demand and has a negative effect on the consistency of the concrete mix - the mix is non-workable after a short time. In practice, the concrete producer, to ensure the appropriate consistency (workability) of the concrete mix in a sufficiently long time, may add larger amounts of water-which ultimately results in lower compressive strength, high concrete shrinkage, and low durability—or the addition of the superplasticizer $\mathrm{P}_{2} \mathrm{O}_{5}$ was observed in the tested ashes, which is related to the type of municipal wastewater delivered to the treatment plant. In the case of ashes obtained from coal combustion, regardless of the technology, the content of $\mathrm{P}_{2} \mathrm{O}_{5}$ is lower than $0.5 \%$. The addition of this ash to concrete will slow down the cement hydration process. As it is known, in the liquid phase of the slurry, $\mathrm{PO}_{4}{ }^{3-}$ ions react with $\mathrm{Ca}^{2+}$ as a result of which, a very sparingly soluble calcium phosphate is precipitated on the surface of the cement grains in the form of a fine crystalline and poorly water-permeable layer, which significantly hinders the cement hydration process. Cement containing an increased amount of soluble 
phosphorus compounds binds more slowly. In the conducted tests, the mixture began to bind the quickest when using the ash from Kraków; the setting started after 30 h, and ended after $40 \mathrm{~h}$.

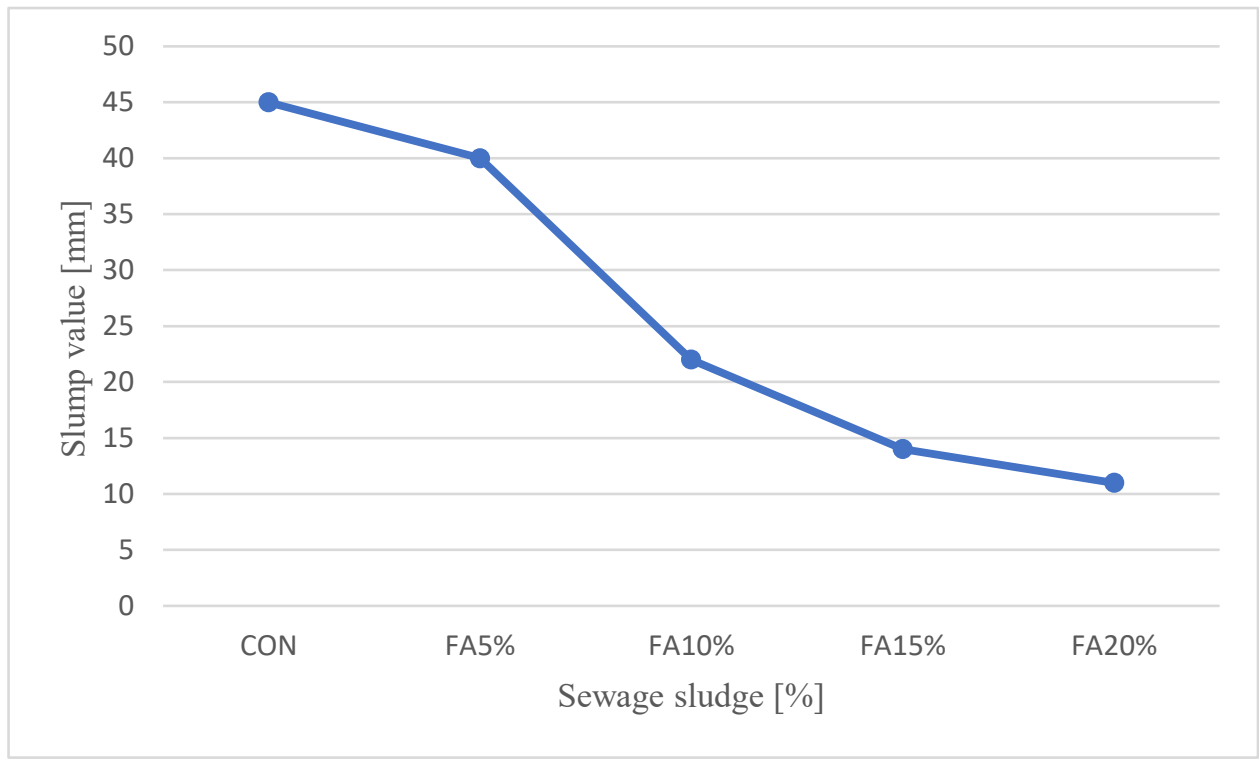

Figure 7. Concrete mix consistency.

The "positive" effect of applying a high-water additive is the reduction in effective water content in the concrete mix, the water/cement ratio (W/C), or the higher levels of squeezing (especially during early seasons) [45].

The research conducted confirms the results of other authors, who have investigated the influence of the presence of fly ash from sewage sludge on the workability of fresh mortar. It was found that replacing cement with ash reduces the workability of the mixture. This can be explained by the irregular structure of the ash grains and the high-water demand of particles with a developed surface [18]. Fly ash from SSA sewage sludge is characterized by significant porosity, which causes intensive water absorption. The factor determining the workability of a given concrete mix is the amount of SSA $[23,63,69,70]$. The workability problem can be reduced by reducing the W/C, or by milling ("lubrication effect) by making the SSA particles spherical, smoother, and less porous [16,35,71-73]. In addition, it was observed that the presence and, above all, the amount of ash from sediments also increases the setting time $[23,69,74,75]$. This is due to the presence of phosphates. The resulting calcium phosphate limits the access of water to the cement particles, thus inhibiting hydration $[74,75]$. To reduce the water absorption, the ash can be ground [73].

In hardened concrete, along with a decrease in the $\mathrm{W} / \mathrm{C}$ ratio; both porosity and water absorption decrease and the compressive strength increases, when the density of the mixture has gained in value from 2320 to $2392 \mathrm{~kg} / \mathrm{m}^{3}$, while the air content increases significantly with the weight of the ash population. The maximum air pollution level is $2.9 \%$ of the mixture in which $25 \%$ of the cement content is added, with a minimum of $1.8 \%$ for the reference mixture without ash. The presented results are based on research performed by other authors $[63,76]$.

\subsection{Compressive Strength}

Figure 8 shows the results of the average compressive strength of the concrete samples with a different content of fly ash taken from the thermal treatment of sewage sludge. The test was performed over three periods of concrete maturation, after 28, 56 and 720 days. The samples were stored in a concrete care bath in water at room temperature $\pm 20{ }^{\circ} \mathrm{C}$. 
Considering the pozzolanic properties and the physico-chemical composition of the used fly ashes from the thermal treatment of sewage sludge, it was observed that the higher concentration of $\mathrm{SiO}_{2}, \mathrm{Al}_{2} \mathrm{O}_{3}$ and $\mathrm{Fe}_{2} \mathrm{O}_{3}$ and lower $\mathrm{P}_{2} \mathrm{O}_{5}$, and $\mathrm{CaO}$ has a positive effect on the increased compressive strength of the concretes produced.

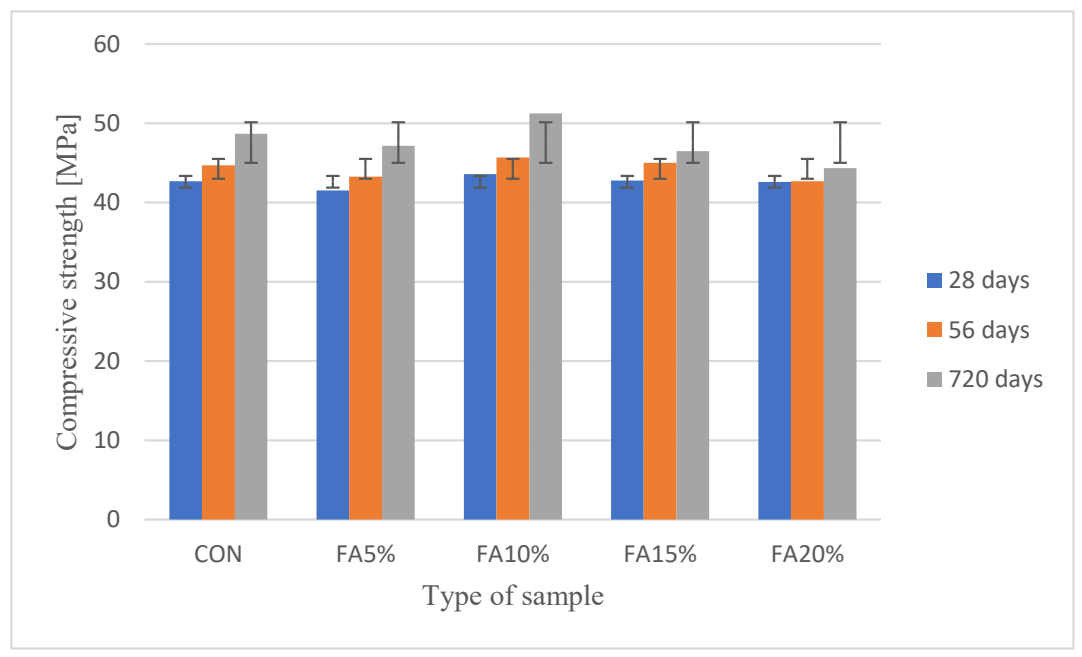

Figure 8. Compressive strength after 28, 56 and 720 days of maturation.

The lowest compressive strength equal to $41.51 \mathrm{MPa}$ after 28 days of maturation was achieved in the concrete samples FA5\%; while the highest one, equal to $43.55 \mathrm{MPa}$, was seen in concrete samples in which $10 \%$ of the cement was exchanged for fly ash. Compared to the reference concrete samples, which reached the value of $42.65 \mathrm{MPa}$, the decrease in strength was $2.7 \%$ and the increase was $2.1 \%$. The highest compressive strength after 56 days of maturation, equal to $45.64 \mathrm{MPa}$, was achieved in the concrete samples FA10\%; while the lowest strength, equal to $42.56 \mathrm{MPa}$, was seen in the concrete samples in which $20 \%$ of the cement was replaced with ash taken from sewage sludge. Taking into account the longest maturation period (720 days); the highest compressive strength equal to $51.23 \mathrm{MPa}$ was achieved in the concrete samples FA10\%, and the lowest strength equal to $44.33 \mathrm{MPa}$ for the FA20\% samples-similar to 56 days of maturing. Compared to the strength determined after the first maturation period, the strength of the FA $10 \%$ samples increased by $17.6 \%$, and the other samples only by $3.9 \%$.

The addition of fly ash from the thermal transformation of sediments increases the strength of the concrete even after the period of standard maturation, i.e., 28 days. It has been proven in the research that the addition of up to $10 \%$ (inclusive) of ash has a positive effect on the increase in strength over time. When increasing the amount of the additive, the increases in strength over time are not as intense. The results of these studies were also confirmed by the authors in previous publications concerning fly ash from the thermal transformation of sludge taken from other wastewater treatment plants [35,60].

Figure 9 shows the increase in compressive strength over time. Based on the obtained results, it was found that the greatest increase of compressive strength, at $17.5 \%$ after 720 days of maturation, was achieved by concrete FA $10 \%$; while concrete FA20\% obtained the lowest one, equal to $4.2 \%$. According to the information presented in other works, the optimal amount of fly ash from thermal treatment of sewage sludge in cement composites ranges from $5 \%$ to $20 \%$. The presence of ash in an amount exceeding $15 \%$ by weight of the cement mass delays the setting process of the slurry and slows the growth of the compressive strength of concretes compared to composites made using only Portland cement. However, by extending the maturation time, the strength required for structural concretes can be obtained $[11,35]$. 


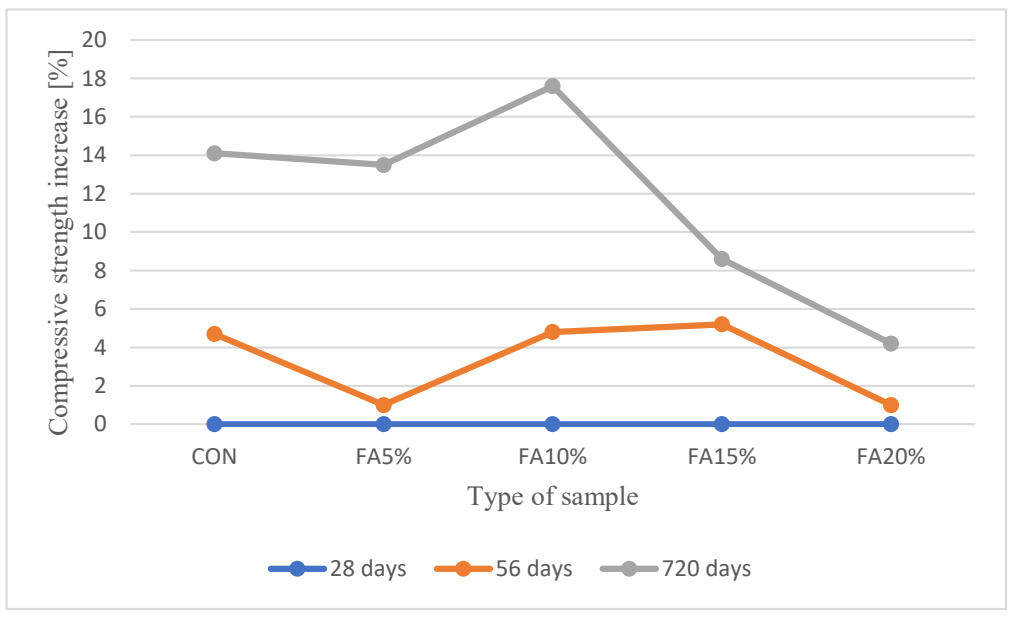

Figure 9. Growth of compressive strength with time.

Other authors, as well as our previous research into the possibility of using fly ash from the thermal transformation of sewage sludge to improve compressive strength, has confirmed its positive influence. Combustion ashes show pozzolanic activity after a longer period, which makes them eligible for active mineral additives. The maximum exchange of the binder-cement to ash-is 5-20\% [11,21,24,31,60]. The use of SSA ashes with a high $\mathrm{CaO}$ content, while maintaining the appropriate $\mathrm{W} / \mathrm{C}$ ratio $(0.5)$, means obtaining mortars and concretes with mechanical properties similar to the reference samples [70]. Satisfactory strength properties can be obtained by using multi-component binders (e.g., CEM II, CEM III), which enhance the ongoing pozzolanic reaction. The mortars and concretes obtained in this way are characterized by good mechanical properties $[25,72]$. Another positive solution is the production of high-strength cement-based composites.

\subsection{Water Penetration Depth under the Tank}

The results obtained from the pressure water penetration tests were performed according to three different concepts: aeration with an air-entraining admixture (group 1); aeration admixture with synthetic microspheres (group 2); and without aeration. Figure 10 shows that none of the tested concretes exceeded $40 \mathrm{~mm}$ of water penetration under pressure. All of recipes prepared guarantee the suitability of concretes made based on fly ash from sewage sludge in structural elements exposed to corrosion caused by chlorides and chemical aggression for the conditions of the exposure class: XS, XD and XA.

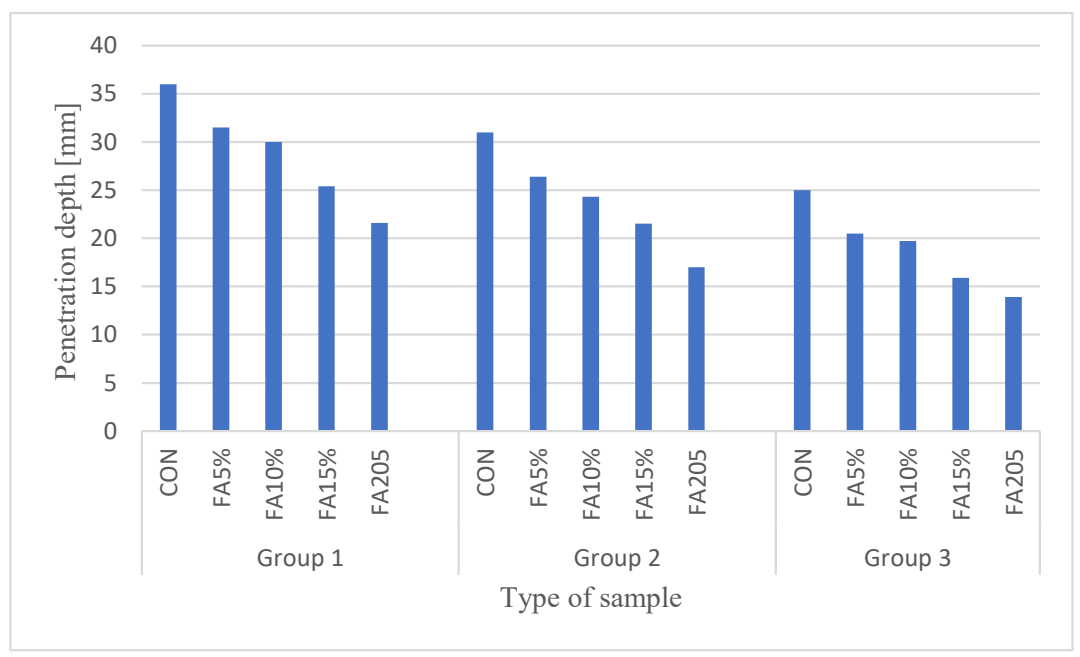

Figure 10. Water penetration depth under the tank. 


\subsection{Carbonation}

One of the main reasons for the destruction of concrete, including reinforced concrete, is carbonation. It is a group of physico-chemical changes in concrete under the influence of long-term exposure to carbon dioxide. During this process, the carbon dioxide in the air reacts with the products of cement hydration. The calcium hydroxide contained in the concrete structure reacts with $\mathrm{CO}_{2}$ in the presence of moisture, resulting in the formation of calcium carbonate and water. The reaction can be written:

$$
\mathrm{Ca}(\mathrm{OH})_{2}+\mathrm{CO}_{2} \rightarrow \mathrm{CaCO}_{3}+\mathrm{H}_{2} \mathrm{O}
$$

In the case of steel reinforced concrete, the carbonation process leads to the inertization of the concrete. Around the reinforcement, due to lowering the $\mathrm{pH}$ level, the passivation layer on the steel is destroyed, which leads to corrosion. Increasing the volume of the reinforcement corrosion products causes stresses in the concrete cover, and consequently leads to cracking and the exposure of the reinforcement [77].

The speed of carbonation advancement depends primarily on the operating conditions of a given element or concrete structure. High humidity and increased $\mathrm{CO}_{2}$ concentration accelerate the carbonation process. A positive effect is the sealing of the microstructure of the cement matrix. The formed calcium carbonate fills the pores in the matrix and the released water supports the hydration of the non-hydrated cement grains. Therefore, the subsurface concrete layer increases its hardness.

Elements of road surfaces and tunnels constitute a particularly exposed group of structures to the carbonation process. The surface of concrete elements in these facilities is cyclically affected not only by water or de-icing salt solutions, but also by carbon dioxide with a concentration higher than in the natural environment $\left(\mathrm{CO}_{2}>0.03 \%\right)$. Concrete technology requirements include increasing the content of the dust particles in the concrete mix, which is achieved by introducing one of the mineral additives, including fly ash [78-80].

The measured depth of carbonation was $1-2 \mathrm{~mm}$, which was undoubtedly influenced by the maturation of the samples in water. A lower depth of carbonation was found in the case of concrete with the addition of fly ash from sewage sludge, which can be explained by its low permeability and, thus, limited range of carbonation. However, the microstructure of concrete with cement, which has an addition, does not protect against carbonation, the speed of which is higher than in the case of concrete made of Portland cement $[78,80]$. Importantly, the rate of carbonation changes over time; therefore, the research that has already started needs to be continued over time, along with the development of a model for this process of creating a specific concrete.

\subsection{Concrete Testing in Elevated Temperature}

The cubic samples were heated at $300{ }^{\circ} \mathrm{C}, 500{ }^{\circ} \mathrm{C}$, and $700{ }^{\circ} \mathrm{C}$, in a special furnace: PK $1100 / 5$ (Termolab S.C., Warsaw, Poland), powered by electricity. The station is equipped with a dedicated ThermoPro program that allows you to program the heating process. The temperature distribution in the tested element was monitored with the use of $\mathrm{NiCr}-\mathrm{Ni}$ thermocouples, which meet the requirements of the standard [81].

Before starting the annealing, all samples were dried to constant weight in a laboratory dryer. The test was performed according to the "temperature-time" standard curve. To determine the heating time at each particular temperature, pilot tests were performed on specially prepared samples in which special holes were made for measuring the thermocouples. After reaching the assumed temperature, the samples were annealed for another $30 \mathrm{~min}$, which was aimed at equalizing the temperature on the outer surface of the sample and throughout its entire volume. The temperature distribution was monitored using four thermocouples. Holes for heating the thermocouples were made in the center of the sample (T3), $25 \mathrm{~mm}$ from the edge of the base (T2), and $10 \mathrm{~mm}$ from the edge of the base (T1). The control thermocouple (TR) was introduced through the back wall and located near the stove ceiling. The drilling depth was $50 \mathrm{~mm}$. The increase in temperature weakened the 
structure of the material. Surface cracks and scratches were visible on the sample surface. The actual example of the temperature distribution is shown in Figure 11, which makes it possible to observe the behavior of the concrete in a fire situation.

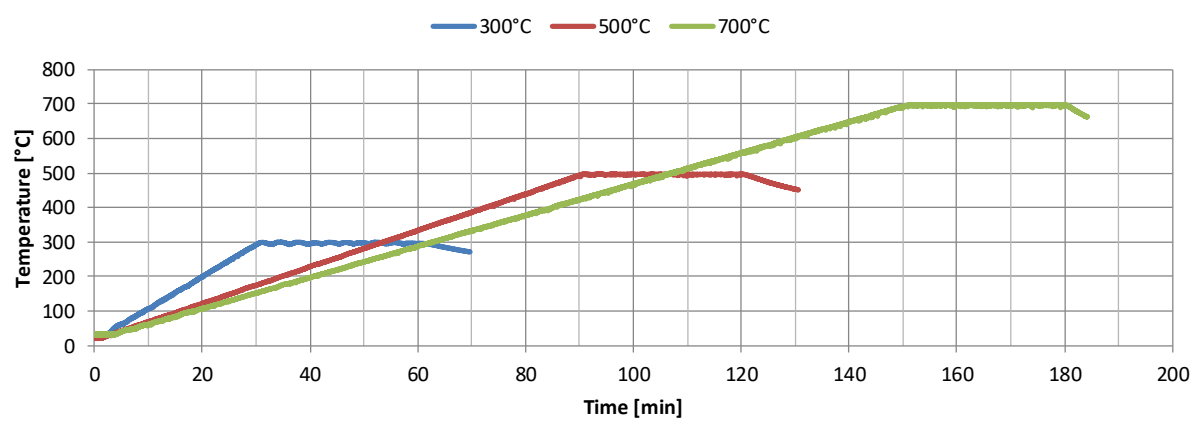

Figure 11. Temperature distribution in the pilot sample- $300^{\circ} \mathrm{C}$ Heating Curve.

Figure 12 shows the results of the average compressive strength of the concrete samples after annealing at different temperatures. The studies performed on the influence of high temperatures confirmed that it is possible to use fly ash from the incineration of sewage sludge in concrete subjected to thermal loads. The annealing itself was carried out in accordance with the assumed schedules (Figure 12). It should be noted, however, that the slope of the curves, and thus the time needed to achieve the set temperatures, was much longer than the time in which these RABT and RWS temperatures are achieved. This was due to the technical limitations of the research furnace used. The achieved characteristics are, however, similar to the so-called standard curve, which is used to test the fire resistance of load-bearing structural elements. No explosive damage to the concrete samples was recorded during the tests. This is due to preparing the samples for the thermal load tests by drying them to a constant mass. Under normal conditions in tunnels, during a fire, explosive spalling is likely to occur due to the elevated dampness of the reinforced concrete linings of the tunnels, which is caused by environmental conditions as well as the conditions of use. The compressive strength tests performed showed that, regardless of the amount of the additive in the form of fly ash from sewage sludge incineration, high temperatures reduce the strength. In each case tested, the temperature of $700{ }^{\circ} \mathrm{C}$ caused a reduction in strength. Notably, in relation to the temperature of $20^{\circ} \mathrm{C}$, the increase in the amount of ash increases the strength of the samples.

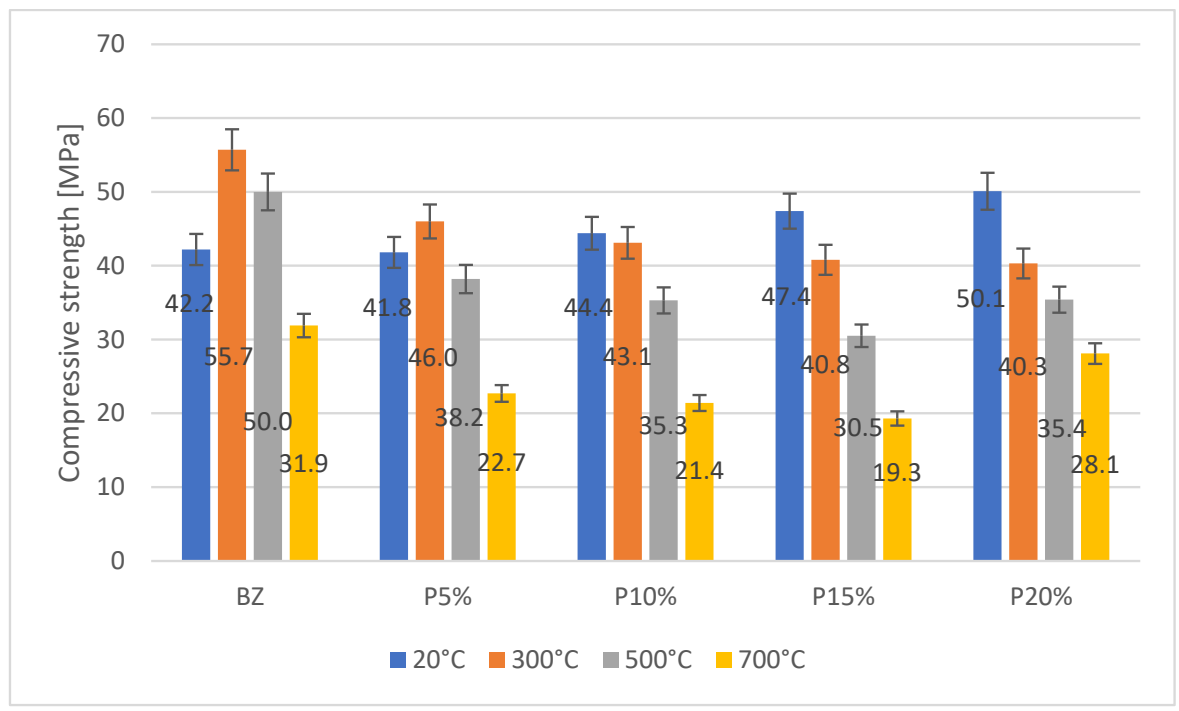

Figure 12. Average compressive strength of thermally loaded samples. 
In the case of ordinary concretes with silicate or limestone aggregate, when heated at $300{ }^{\circ} \mathrm{C}$, the decrease in compressive strength is up to $10 \%$ in relation to the normal temperature. The results of our tests showed that for BZ and P5\% samples the strength increased. It is difficult to clearly define what factors caused this phenomenon; perhaps it is influenced by the type of aggregate used. Nevertheless, this temperature, even in relation to ordinary concrete and the abovementioned aggregates, does not always have a negative impact on strength, as it is also dependent on the class of concrete, humidity of the tested samples, method of heating, and several other secondary factors, such as the method of concrete care.

\section{Conclusions}

According to the regulations in force in Poland (Journal of Laws of 2016, item 108), which implement the Directive of the European Parliament and of the Council (EU/2010/75), the resulting fly ash from the incineration of sewage sludge, after meeting certain requirements, can be used as an additive in the preparation of concrete mixtures. The studies conducted so far indicate that the use of ashes from the thermal treatment of sewage sludge as an additive to concrete, allows for comparable properties to concrete produced based on fly ashes from coal combustion or co-combustion to be obtained. Research has shown that fly ash can perfectly replace cement, a hydraulic mineral binder obtained from mineral raw materials [82,83]. By analyzing the results and the observations obtained during the conducted experimental studies, it was found that:

1. The fly ashes obtained from the thermal transformation of sewage sludge produced in the sewage treatment plant and used for the preparation of ordinary concrete had a positive effect on its properties: compressive strength, depth of water penetration under pressure, and carbonation.

2. Concrete produced based on fly ash from sewage sludge combustion was characterized by a compressive strength comparable to that of the reference concrete without addition after 28, 56 and 720 maturation days. The increase in strength over time resulted in an increase in the class of concrete from C20/25 to C35/40.

3. No explosive spalling of the samples occurred during heating. This was likely due to drying the samples to a constant weight before heating them.

4. The compressive strength tests conducted after annealing showed that the addition of fly ash did not affect the strength. The obtained results were similar in the temperature range $300-700{ }^{\circ} \mathrm{C}$. It has been shown that with the increase in heating temperature, the strength of the samples decrease, regardless of the amount of additive in the form of ash.

5. Fly ash from thermal sludge treatment does not meet the requirements of PN-EN 4501:2012. However, there are no legal regulations regarding the physical and chemical properties of ash from sludge incineration; nor are there specifications concerning the possibility of their use in concrete technology. The highest percentage of the ash samples were oxides of silicon, calcium, phosphorus, and aluminum.

The conducted experimental work confirmed the positive effect of fly ash from the thermal conversion of sewage sludge on selected properties of concretes produced with their participation. However, information regarding the testing of resistance of these concretes to high temperature is limited. The materials presented in this article constitute the basis for further research in this field. Due to the lack of regulations and standards for the use of fly ash obtained from the thermal treatment of sewage sludge, further detailed interpretation of the results requires supplementary studies. 


\begin{abstract}
Author Contributions: Author Contributions: Conceptualization, G.R., P.O.; methodology, G.R., P.O.; software, G.R. and P.O.; validation, G.R. and P.O.; formal analysis, G.R. and P.O.; investigation, G.R. and P.O.; resources, G.R. and P.O.; data curation, G.R. and P.O.; writing-original draft preparation, G.R., P.O. and M.Ż.; writing-review and editing, G.R., P.O. and M.Ż.; visualization, M.K. (Martin Krejsa) and A.P.; supervision, M.K. (Michał Kucharski). All authors have read and agreed to the published version of the manuscript.
\end{abstract}

Funding: This research received no external funding.

Institutional Review Board Statement: Not applicable.

Informed Consent Statement: Not applicable.

Data Availability Statement: The data presented in this study are available on request from the corresponding author.

Conflicts of Interest: The authors declare no conflict of interest.

\title{
References
}

1. Larsson, K. Fires in Tunnels and Their Effect on Rock; Luleå University of Technology Department of Civil and Environmental Engineering: Luleå, Sweden, 2006.

2. Promat. Tunnel \& Underground Structure Fire Protection. 2008. Available online: https://www.promat.com/- /dam/promattunnels-sprays-manual-2018---eng/pd17393/original/promat-tunnels-sprays-manual-2018---eng.pdf?v=0 (accessed on 2 August 2021).

3. Vouk, D.; Nakic, D.; Stirmer, N.; Cheeseman, C.D. Use of sewage sludge ash in cementitious materials. Rev. Adv. Mater. Sci. 2017, $49,158-170$.

4. Yang, T.; Huang, H.; Lai, F. Pollution hazards of heavy metals in sewage sludge from four wastewater treatment plants in Nanchang, China. Trans. Nonferr. Metals Soc. 2007, 27, 2249-2259. [CrossRef]

5. Wichowski, P.; Rutkowska, G.; Nowak, P. Elution of selected heavy metals from concretes containing ashes produced in thermal conversion of sludge. Acta Sci. Pol. Architect. 2017, 16, 43-51.

6. Uliasz-Bocheńczyk, A.; Mazurkiewicz, M.; Mokrzycki, E. Fly ash from Energy production-A waste, by product and raw material. Miner. Res. Manag. 2015, 31, 139-150. Available online: https://www.researchgate.net/publication/292816258_Fly_ash_from_ energy_production_-_A_waste_byproduct_and_raw_material (accessed on 12 November 2021).

7. Kepys, W.; Pomykała, R.; Pietrzyk, J. Properties of fly ash from thermal conversion of municipal sewage sludge. J. Polish. Miner. Eng. Soc. 2013.

8. Piotrowski, Z.; Uliasz-Bocheńczyk, A. Possibilities of economic utilization of waste from fluidized bed boilers. Miner. Res. Manag. 2008, 24, 73-85.

9. Wang, W.; Lu, C.; Li, Y.; Yuan, G.; Li, Q. Effects of stress and high temperature on the carbonation resistance of fly ash concrete. Constr. Build. Mater. 2017, 138, 486-495. [CrossRef]

10. Yadav, S.; Agnihotri, S.; Gupta, S.; Tripathi, R. Incorporation of STP Sludge and Fly ash in Brick Manufacturing: An attempt to save the Environment. IJOAR 2014, 3, 138-144. [CrossRef]

11. Yen, C.L.; Tseng, D.H.; Lin, T.T. Characterization of eco-cement paste produced from waste sludges. Chemosphere 2011, 84, 220-226. [CrossRef]

12. Fontes, C.M.A.; Barbosa, M.C.; Toledo Filho, R.D.; Goncalves, J.P. Potentiality of sewage sludge ash as mineral additive in cement mortar and high performance concrete. In Proceedings of the Use of Recycled Materials in Buildings and Structures (RILEM Publications), Barcelona, Spain, 8-11 November 2004; pp. 797-806.

13. Yusur, R.O.; Noor, Z.Z.; Din, M.D.F.M.D.; Abba, A.H. Use of sewage sludge ash (SSA) in the production of cement and concrete-a review. Int. J. Glob. Environ. Issues 2012, 12, 214-228.

14. Belviso, C. State-of-the-art applications of fly ash from coal and biomass: A focus on zeolite synthesis processes and issues. Prog. Energy Combust. Sci. 2018, 65, 109-135. [CrossRef]

15. Cyr, M.; Coutand, M.; Clastres, P. Technological and environmental behavior of sewage sludge ash (SSA) in cement-based materials. Cem. Concr. Res. 2007, 37, 1278-1289. [CrossRef]

16. Monzo, J.; Payá, J.; Borrachero, M.V.; Morenilla, J.J.; Bonilla, M.; Caldero, P. Some strategies for reusing residues from waste water treatment plants: Preparation of building materials. In Proceedings of the Use of Recycled Material in Building and Structures, Barcelona, Spain, 8-11 November 2004.

17. Monzó, J.; Paya, J.; Borrachero, M.V.; Peris-Mora, E. Mechanical behaviour of mortars containing sewage sludge ash (SSA) and Portland cements with different tricalcium aluminate content. Cem. Concr. Res. 1999, 29, 87-94. [CrossRef]

18. Monzó, J.; Paya, J.; Borrachero, M.V.; Girbes, I. Reuse of sewage sludge ashes (SSA) in cement mixtures: The effect of SSA on the workability of cement mortars. Waste Manag. 2003, 23, 373-381. [CrossRef]

19. Merino, I.; Arévalo, L.F.; Romero, F. Preparation and characterization of ceramic products by thermal treatment of sewage sludge ashes mixed with different additives. Waste Manag. 2007, 27, 1829-1844. [CrossRef] 
20. Lin, K.L. The influence of municipal solid waste incinerator fly ash slag blended in cement paste. Cem. Concr. Res. 2005, 35, 979-986. [CrossRef]

21. Lin, K.L.; Lin, C.Y. Hydration characteristics of waste sludge ash utilized as raw cement material. Cem. Concr. Res. 2005, 35, 1999-2007. [CrossRef]

22. Tay, J.H.; Show, K.Y. Resource recovery of sludge as a building and construction material—A future trend in sludge management. Water Sci. Technol. 1997, 36, 259-266. [CrossRef]

23. Chang, F.; Lin, J.; Tsai, C.; Wang, K. Study on cement mortar and concrete made with sewage sludge ash. Water Sci. Technol. 2010, 62, 1689-1693. [CrossRef]

24. Ferreira, C.; Ribeiro, A.; Ottosen, L. Possible applications for municipal solid waste fly ash. J. Hazard. Mater. 2003, 96, 201-216. [CrossRef]

25. Baeza-Brotons, F.; Garces, P.; Paya, J.; Saval, J.M. Portland cement systems with addition of sewage sludge ash. Application in concretes for the manufacture of blocks. J. Clean. Prod. 2014, 82, 112-124. [CrossRef]

26. Chen, M.; Blanc, D.; Gautier, M.; Mehu, J.; Gourdon, R. Environmental and technical assessments of the potential utilization of sewage sludge ashes (SSAs) as secondary raw materials in construction. Waste Manag. 2013, 33, 1268-1275. [CrossRef] [PubMed]

27. Kosior-Kazberuk, M. New mineral additives for concrete. Constr. Environ. Eng. 2011, 29, 47-55.

28. Tarko, B.; Gorazda, K.; Wzorek, Z.; Nowak, A.K.; Kowalski, Z.; Kulczycka, J.; Henclik, A. Recovery of phosphorus from industrial sewage sludge ashes. Chem. Ind. 2014, 93, 1041-1044.

29. Małolepszy, J.; Tkaczewska, E. Influence of Fly Ashes from Co-Combustion of Coal and Biomass on the Hydration Process and Cement Properties. In Proceedings of the 4th Conference "Concrete Days-Tradition and Modernity", Wisła, Poland, 9-11 October 2006; Cement Producers Association: Krakow, Poland, 2006; pp. 591-601.

30. Lind, B.B.; Norrman, J.; Larsson, L.B.; Ohlsson, S.A.; Bristav, H. Geochemicals anomalies from bottom ash in a road constructionComparison of the leaching potential between an ash road and the surroundings. Waste Manag. 2008, 28, 170-180. [CrossRef]

31. Shirodkar, P.; Sonpal, K.; Norton, A.; Weaver, R.; Tomlinson, C.; Nolan, A.; Mehta, Y.; Jahan, K. Evaluation of fatigue and rutting performance of sewage sludge ash (SSA) in asphalt Concrete. J. Solid Waste Technol. Manag. 2011, 37, 55-60. [CrossRef]

32. Tenza-Abril, A.J.; Saval, J.M.; Cuenca, A. Using sewage-sludge ash as filler in bituminous mixes. J. Mater. Civ. Eng. 2014, 27, 1-9. [CrossRef]

33. Ingunza, M.D.P.D.; Camarini, G.; da Costa, F.M.S. Performance of mortars with the addition of septic tank sludge ash. Construct. Build. Mater. 2018, 160, 308-315. [CrossRef]

34. Spinosa, L.; Ayol, A.; Baudez, J.-C.; Canziani, R.; Jenicek, P.; Leonard, A.; Rulkens, W.; Xu, G.; Van Dijk, L. Sustainable and innovative solutions for sewage sludge management. Water 2011, 3, 702-717. [CrossRef]

35. Rutkowska, G.; Wichowski, P.; Fronczyk, J.; Franus, M.; Chalecki, M. Use of fly ashes from municipal sewage sludge combustion in production of ash concretes. Constr. Build Mater. 2018, 188, 874-883. [CrossRef]

36. Haukur Ingason: Design fire curves for tunnels. Fire Saf. J. 2009, 44, 259-265. [CrossRef]

37. de Jong, M. History of the RWS Fire Curve. 2020. Available online: https://www.linkedin.com/pulse/history-rws-fire-curvemicha-de-jong (accessed on 2 August 2021).

38. Kalifa, P.; Menneteau, F.D.; Quenard, D. Spalling and porepressure in HPC at high temperature. Cem. Concr. Res. 2000, 1, 1915-1927. [CrossRef]

39. Zheng, Z. Experimental study on concrete spalling in prestressed slabs subjected to fire. Fire Saf. J. 2010, 45, 283-297. [CrossRef]

40. Gawin, D.; Schrefler, B.A. Thermo-hydro-mechanical analysis of partially saturated porous materials. Eng. Comput. 1996, 13, 113-143. [CrossRef]

41. Hager, I. Behaviour of cement concrete at high temperature. Pol. Acad. Sci. Tech. 2013, 61, 145-154. [CrossRef]

42. Taillefer, N.; Pimienta, P.; Dhima, D. Palling of Concrete: A Synthesis of Experimental Tests on Slabs. In Proceedings of the 3rd International Workshop on Concrete Spalling due to Fire Exposure, Paris, France, 25-27 September 2013.

43. Ogrodnik, P.; Szulej, J.; Franus, W. The Wastes of Sanitary Ceramics as Recycling Aggregate to Special Concretes. Materials 2018, 11, 1275. [CrossRef]

44. Szulej, J.; Ogrodnik, P.; Klimek, B. Zeolite tuff and recycled ceramic sanitary ware aggregate in production of concreto. Sustainability 2019, 11, 1782. [CrossRef]

45. PN-EN 206+A2:2021-08. Concrete. Lot 1: Requirements, Properties, Production and Compliance. Available online: https: / / sklep.pkn.pl (accessed on 19 December 2021).

46. PN-EN 197-1:2012; Cement-Part 1: Composition, Requirements and Compliance Criteria for Common Cements. BSI: London, UK, 2012.

47. EN 12620+A1:2010. Aggregate for Concreto. Available online: https://sklep.pkn.pl (accessed on 19 December 2021).

48. EN 1008:2004; Mixing Water for Concreto. iTeh Standards: Etobicoke, ON, Canada, 2004. not published.

49. PN-EN 12350-6:2011; Testing of Fresh Concrete. Part 6: Density. iTeh Standards: Etobicoke, ON, Canada, 2019.

50. PN-EN 12350-2:2011; Testing of Fresh Concrete. Part 2. Slump Test. iTeh Standards: Etobicoke, ON, Canada, 2019.

51. PN-EN 12350-7:2011; Testing of Fresh Concrete. Part 7: Air Content-Pressure Method. iTeh Standards: Etobicoke, ON, Canada, 2019.

52. PN-EN 12390-3:2019-07; Testing of Hardened Concrete. Part 3: Compressive Strength of Test Specimens. iTeh Standards: Etobicoke, ON, Canada, 2019. 
53. PN-EN 12390-8:2019-08; Concrete Tests-Part 8: Penetration Depth of Water Under Pressure. iTeh Standards: Etobicoke, ON, Canada, 2019.

54. PN-EN 13295:2005; Products and Systems for the Protection and Repair of Concrete Structures-Test Methods-Determination of Resistance to Carbonation. iTeh Standards: Etobicoke, ON, Canada, 2004.

55. PN-EN 450-1:2012; Fly Ash for Concrete. Part 1: Definition, Specifications and Conformity Criteria. Polish Standardization Committee: Warsaw, Poland, 2012.

56. ASTM. C379-65T Specification for Fly Ash for Use as a Pozzolanic Material with Lime; ASTM International: West Conshohocken, PA, USA, 1996

57. Tkaczewska, E.; Kłosek-Wawrzyn, E. The influence of $\mathrm{PO}_{4}{ }^{3-}$ phosphate ions on the cement hydration process. Cem. Lime Concrete. 2012, R.17/79, nr6, 401-408.

58. Williams, P.T. Waste Treatment and Disposal, 2nd ed.; John Wiley \& Sons: Chichester, UK, 2005.

59. Tkaczewska, E. Properties of cements containing various grain fractions of silica fly ash. Roads Bridges 2008, 4, 47-80.

60. Rutkowska, G. Fly ash from thermal treatment of sewage sludge as an additive to ordinary concretes. Acta Sci. Pol. Archit. 2021, 19, 93-104.

61. PN-EN 1097-07:2008; Determination of the Filler Density. BSI International: London, UK, 2009.

62. PN-EN 451-2:2017-06; Fly Ash Test Method-Determination of Fineness by Wet Sieving. iTeh Standards: Etobicoke, ON, Canada, 2017.

63. Chen, Z.; Poon, C.S. Comparative studies on the effects of sewage sludge ash and fly ash on cement hydration and properties of cement mortars. Construct. Build. Mater. 2017, 154, 791-803. [CrossRef]

64. Naamane, S.; Rais, Z.; Taleb, M. The effectiveness of the incineration of sewage sludge on the evolution of physicochemical and mechanical properties of Portland cement. Construct. Build. Mater. 2016, 112, 783-789. [CrossRef]

65. Avet, F.; Boehm-Courjault, E.; Scrivener, K. Investigation of C-A-S-H composition, morphology and density in limestone calcined clay cement (LC3). Cem. Concr. Res. 2019, 115, 70-79. [CrossRef]

66. Balonis, M. Hermodynamic modelling of temperature effects on the mineralogy of Portland cement systems containing chloride. Cem. Concr. Res. 2019, 120, 66-76. [CrossRef]

67. Lynn, C.J.; Dhir, R.K.; Ghataora, G.S.; West, R.P. Sewage sludge ash characteristics and potential for use in concrete. Construct. Build. Mater. 2015, 98, 767-779. [CrossRef]

68. Li, J.S.; Guo, M.Z.; Xue, Q.; Poon, C.S. Recycling of incinerated sewage sludge ash and cathode ray tube funnel glass in cement mortars. J. Clean. Prod. 2017, 152, 142-149. [CrossRef]

69. Naamane, S.; Rais, Z.; Taleb, M.; Mtarfi, N.H.; Sfaira, M. Sewage sludge ashes: Application in construction materials. J. Mater. Environ. Sci. 2016, 7, 67-72.

70. Vouk, D.; Serdar, M.; Vucinic, A.A. Use of incinerated sewage sludge ash in cement mortars: Case study in Croatia. Teh. Vjesn. Tech. Gaz. 2017, 24, 43-51. [CrossRef]

71. Chen, Z.; Li, J.S.; Poon, C.S. Combined use of sewage sludge ash and recycled glass cullet for the production of concrete blocks. J. Clean. Prod. 2018, 171, 1447-1459. [CrossRef]

72. Kappel, A.; Ottosen, L.M.; Kirkelund, G.M. Colour, compressive strength and workability of mortars with an iron rich sewage sludge ash. Construct. Build. Mater. 2017, 157, 1199-1205. [CrossRef]

73. Pan, S.C.; Tseng, D.H.; Lee, C.C.; Lee, C. Influence of the fineness of sewage sludge ash on the mortar properties. Cement Concr. Res. 2003, 33, 1749-1754. [CrossRef]

74. Mejdi, M.; Saillio, M.; Chaussadent, T.; Divet, L.; Tagnit-Hamou, A. Hydration mechanisms of sewage sludge ashes used as cement replacement. Cement Concr. Res. 2020, 135, 106-115. [CrossRef]

75. Piasta, W.; Lukawska, M. The effect of sewage sludge ash on properties of cement composites. Procedia Eng. 2016, 161, 1018-1024. [CrossRef]

76. Rutkowska, G.; Wichowski, P.; Franus, M.; Mendryk, M.; Fronczyk, J. Modification of Ordinary Concrete Using Fly Ash from combustion of Municipal Sewage Sludge. Materials 2020, 13, 487. [CrossRef]

77. Piasta, J.; Sawicz, Z.; Piasta, W. Carbonating Process of Concrete in Steel Reinforced Slab. In Proceedings of the Conference Concrete Days, Nanjing, China, 13-15 October 2008.

78. Jensen, O.M.; Hansen, P.F. Water entrained cement-based materials. I. Principles and theoretical background. Cem. Concr. Res. 2001, 31, 647-654. [CrossRef]

79. Snoeck, D.; Schaubroeck, D.; Dubruel, P.; De Belie, N. Effect of high amounts of superabsorbent polymer and additional water on the workability, microstructure and strength of mortars with water-to-cement ration of 0.50. Constr. Build. Mater. 2014, 72, 148-157. [CrossRef]

80. Justs, J.; Wyrzykowski, M.; Bajare, D.; Lura, P. Internal curing by superabsorbent polymers in ultra-high performace concrete. Cem. Concr. Res. 2017, 97, 73-83.

81. IEC 60584-1:2013; Thermocouples. Part 1: EMF Specifications and Tolerances. iTeh Standards: Etobicoke, ON, Canada, 2013. 
82. Regulation of the Minister of Development of 21 January 2016 on the Requirements for the Thermal Waste Treatment Process and the Methods of Handling Waste Resulting from This Process. Dz.U. 2016 poz.108. Available online: http://isap.sejm.gov.pl/isap. nsf/DocDetails.xsp?id=WDU20160000108 (accessed on 2 August 2021).

83. EU/2010/75. Directive 2010/75/UE of the European Parliament and the Council of 24 November 2010 on Industrial Emissions (Integrated Pollution Prevention and Control). Available online: https://eur-lex.europa.eu/legal-content/RO/TXT/?uri= CELEX\%3A32010L0075 (accessed on 15 August 2021). 